\title{
InTRODUCTION: HANNAH ARENDT'S LEGACY AT 100 YeARS OF HER BirTH*
}

\author{
SIMONA FORTI \\ Università del Piemonte Orientale, Italia
}

Hannah Arendt did not particularly like celebrations. She used to say that even in the most somber of occasions, as in the middle of a funeral ceremony, the rhetoric of commemoration could make her burst out in laughter. How, then, while respecting her ironical, idiosyncratically elegant sensibility, should we remember her in the one-hundreth anniversary of her birth? Perhaps by revisiting her thought in a roundabout way; by quickly passing under review the most significant moments that have turned her into a central figure of political and cultural debates. If until the 1960s she was known only as the polemical scholar of totalitarianism or as the creator of the contested formula on the "banality of evil", today Arendt's legacy must confront a notoriety that, in its excessiveness, runs the risk of banalizing her. In the last decade, in particular, the media circus that has drawn in, for better or for worse, even philosophy, has been flooded with images of Hannah Arendt.

Before considering some of the consequences that derive from this excessive "publicity", it is useful to recall that the author received her consecration as a "classic" of political philosophy exactly thirty years ago. In an article which appeared in German in 1976, and was quickly translated into English, French, Italian and Spanish, Jürgen Habermas identified The Human Condition -the great work of Arendt of 1958- as the founding text of the revival of practical philosophy, in general, and of the "theory of communicative action", in particular. The Human Condition had systematically elaborated the arguments that redeemed praxis, political action, from its instrumental and subordinate function with respect to other spheres of human activity. The heir to the Frankfurt School, however, envisaged a great limitation in Arendt's political philosophy: its rigid normativism, sustained by an ingenuous faith in the unchanging character of "intersubjectivity" and by an anachronistic return to Greek political thought. Habermas claimed that Arendt's "hypostatization of the image of the polis", projected as the very essence of politics, together with her being caught in "the vice of an Aristotelian theory of action", made it hard for her to understand the modern state and society. In order to make use of her great intuition regarding the dignity and authenticity of politics, he suggested the need to "reclaim" the Arendtian landscape: eliminate its more extremist and irrationalistic, anti-modern and nostalgic elements in order to "civilize" her thought and make it compatible with the so-called project of modernity, interpreted according to the criteria of post-Kantian critical theory. 
In the context of current German philosophy, as in the current North-American cultural context marked by neo-Aristotelian presuppositions, Habermas's evaluation has become a sort of interpretative paradigm of its own, from which it has not been easy to free Hannah Arendt's philosophy (Forti, 2006). ${ }^{1}$ In spite of the sophistication and varieties of interpretations, this "first wave" of the debate is unanimous in considering Arendt's thought as a theoretical model that puts forward an anti-modern normative project, to which one can either subscribe or take one's distance. Of course, all sorts of contrasting political tendencies are attributed to Arendt: she is accused of being aristocratic-elitist and at the same time populist-revolutionary. Some see in her work a conservative attitude, while others see in her a defender of liberal democracy. She is charged with rehabilitating "republicanism" and at the same time with being an anarchist. But in every case these readings all identify the constitutive limit of her thought as being its failure to acknowledge "realistically" the difference between ancients and moderns. In short, her concept of politics posits too many restrictive preconditions in order to realize its authenticity. Furthermore, by eliminating every strategic and instrumental element from her definition of power, Arendt's thought remains inadequate both in order to think through the nature of power and, as a consequence, in order to delineate an effective alternative to domination.

Undoubtedly, if one is set on reading Arendt as a normative thinker, Habermasians and communitarians are right in pointing out her strong ambiguities, her lacks, her contradictions. But the point is just that: maybe all of these normative readings of Arendt have missed the strategic and polemical element in her critique of politics, a critique which refuses to consider the means-end relation as constitutive of praxis, and which rejects all philosophies that desire to impose a regulative model on political coexistence. In my opinion, the attempt by post-Kantians and post-Aristotelians to "gentrify" the Arendtian "province" has revealed itself as nothing short of an attempt at "normalization'.

Starting in the mid-eighties (in the Italian context one thinks of the works and editions by Boella, Dal Lago, Esposito, Flores, Galli, Portinaro; and in France of those by Enegren, Collin, Taminiaux, Nancy and Lacoue-Labarthe), the "second wave" of the reception, so to speak, comes to terms in a productive manner with the aporias, contradictions and ambivalences of Hannah Arendt's thought. One could even say that this reception turns these apparent weaknesses into elements of the greatness of her thought: a thought that remains resolutely uncontextualizable, moving in a space inhabited by the many figures of the pariah that populate her writings. If it is true that in this second reception Arendt's philosophy was recognized as following on the footsteps of the fundamental critiques of metaphysics and dialectics of the early 20th century -particularly the Nietzschean and Heideggerian deconstructions of the tradition- at the same time this reception acknowledged that Arendt's thought could never be reduced to one school of thinking. Phenomenology and existentialism remain crucial philosophical reference points, but they interact in her thought with a loyalty towards worldly events that undermines disciplinary divisions and deviates from the trajectories of theoretical orthodoxies. Any precise attempt to define the political camp of the author becomes besides the point.

I think that today one can take it for granted that any analysis of Arendt's work that does not take into account its dual origin -the historical and tragical events the author lived through and the

1 For precise references to the history and the protagonists of the reception of Hannah Arendt, I permit myself to refer to the new edition of my book, S. Forti, 2006, Hannah Arendt tra filosofia e politica (Milano: Bruno Mondadori). 
horizon opened up by Heidegger's philosophy-cannot but be reductive. Nonetheless, together with very sophisticated readings that continue to complicate the problematic nodes in her discourse, today we are also witnessing a "re-normalization" of Arendt's philosophy. This re-normalization spreads a kind of common sense which holds that her thought is reducible to a couple of trite formulas, good for many occasions, concerning the authenticity and openness to alterity found in an egalitarian and democratic political life, or the need to search for an intersubjective consensus that safeguards and recognizes differences.

Faced with this kind of "do-good" Arendtianism, I think that she needs to be taken seriously once again. That is to say, it is crucial to situate her undisputed and often-mentioned "anomaly" -as an exile, as a non-Zionist Jew, as a woman who thinks in an intellectual cosmos that is entirely masculine, as a philosopher that wants to leave metaphysics behind, as a libertarian that never weds liberalism, as a critic of Marxism that attacks repentant ex-communists and points out the totalitarian tendencies in the United States during Maccarthyism and the Vietnam War- back into its proper theoretical depth and conceptual rigor. In other words, I think that one must re-emphasize that her new conception of power -which is all too often considered to be merely preparatory to a politics based on consensus and reconciliation- is in fact "agonistic" and, under many respects, "tragic" precisely because of its aporetic character. This aporetic character is due to the fact that her theory is bound up with a critique of the philosophical tradition that buried the dissonances of the real under its metaphysical and political machinery of reductio ad unum. Likewise, it is important to remember that for Arendt the deconstruction of a political and metaphysical tradition is not equivalent to critically investigating a historical chain of ideas and doctrines, connected one to the other by the same oblivion of the authentic meaning of being. Rather, Arendt's deconstruction of the tradition also means understanding these ideas and doctrines as signs, at once extreme and yet everyday and normal, of that relationship between individual and world, between self-construction and perception of the other, that has characterized western culture. In other words, the mind of the "professional philosopher" not only is not a privileged access to the understanding of being, but it is not even an isolated or rare attitude. Instead, the professional philosopher's mind-set, in a sui generis form, is emblematic of a typical and frequent attitude of denial found in modern subjectivity. This approach to Arendt's relation to the Heideggerian legacy is, in many ways, analogous to the one shared by continental philosophy in the second half of the twentieth century, and brings Arendt closer to thinkers like Foucault and Derrida than to theorists like Habermas.

Perhaps it is from this point that one could begin to appreciate anew the richness, but also the difficulty, of Arendtian politics. Just as it is from here that one should proceed, together with Hannah Arendt but going beyond her, in order to meet the challenges set by a world that is today in part very different from what it was in her time. Only in this way can we "honor" Arendt's legacy and celebrate her greatness as a thinker, she who would never ask us to remain the exegetes of her writings nor to translate into practice her thoughts. And this also because at the heart of her thinking stands the sense of reality as something that constantly exceeds and upsets the projects that theory withholds for it.

Simona Forti es profesora titular ordinaria de historia del pensamiento político contemporáneo de la Facoltà di Scienze Politiche de la Università del Piemonte Orientale. Entre sus últimos libros se encuentran: L'idea di totalitarismo (1997, Roma-Bari: Laterza) y Ridefinire la política (1999, Milano: Feltrinelli).

(E-mail: simona.forti@sp.unipmn.it) 
